\title{
INFLUENCE OF TECHNOLOGY ON REGIONAL BRANDS IN CZECHIA
}

pages: $92-102$

\author{
MICHAL STOKLASA
}

\begin{abstract}
A B S TR A C T
This article aims to examine the effects of new technology on the purchase of regional brands in Czechia and draw conclusions that will help to adapt the brands to customer needs. Regional brands are a speciality of Central Europe, which emerged due to consumer dissatisfaction with low-quality of global retail products. These traditional local handmade products are heavily influenced by new technology and customers requiring them to be purchasable online with a massive online presence. The sample consisted of 1050 residents of the Czech Republic. The data were gathered by a professional marketing agency Ipsos using a questionnaire survey. The sample was tested using the one-way Chi-square test, which had good compliance to test the basic sample characteristics, followed with the one-sample Kolmogorov-Smirnov test to test the data distribution, and then, the dependencies were tested with the Kruskal-Wallis test. Finally, a post-hoc test suitable for the type of analysis could be chosen to better understand the type of factors that could influence the results and their possible effect. The main findings indicate a slow change in the demand as customers are neutral in relation to regional brands available from online shops as well as their about social media presence but require them to have a good-quality website. Solutions are proposed using a government-run brand with a platform providing web layouts and hybrid e-shop. The type of content is proposed, indicating the appropriate execution, which should be done based on the researched-derived segmentation criteria.
\end{abstract}

KEY WORDS

regional brands, regional product, Kruskal-Wallis test, technology

DOI: 10.2478/emj-2019-0036
Corresponding author:

Michal Stoklasa

Silesian University, Czech Republic e-mail: stoklasa@opf.slu.cz

\section{INTRODUCTION}

The analysis of articles from the Web of Science (WoS) and Scopus databases demonstrated that regional brands for regional products were a speciality of Central Europe (Stoklasa and Pitrunová, 2018) and it gained a lot of traction from consumers dissatisfied with low-quality global retail products. However, this scientific area remains under- researched. Regional brands are certified for regional products that are traditional and locally handmade; however, they are nowadays heavily influenced by new technology and "new age" customers who demand them to be purchasable online with a massive online presence. However, the operating principle of regional brands (fan-driven, limited budget) does not allow them to pursue new trends easily. The 
technological trends that are transforming this industry might be acceptable for multinational companies with sufficient resources; however, regional brands have many limitations and have to selectively choose on what to focus. Thus, the need arises to explore feasible technological advances and their possible incorporation into the way how regional brands function.

A review of the relevant literature has shown a research gap regarding regional branding in general and the impact of technology on regional brands in particular (Stoklasa and Pitrunová, 2018). The initial study into this area (Pitrunová and Stoklasa, 2018) revealed that brands used very limited communication tools, mostly only websites of, sometimes, dubious quality and ignored other online channels. No other articles in WoS and Scopus databases were found to deal with the influence of technology on regional brands and their products (Stoklasa and Pitrunová, 2018). Therefore, this research topic is important to provide some understanding of how the new technology is changing the way regional brands function, and how these new tools can be used to benefit consumers.

This article aims to examine the effects of new technology on the purchase of regional brands in Czechia and draw conclusions that will help the brands to adapt to their customer needs. The regional brands are defined together with the theoretical basis for the research. Next, the methodology is examined. The sample consisted of 1050 residents of the Czech Republic, and the data were gathered by Ipsos using a questionnaire. Following the general presentation of the results, the data were tested using the one-way Chi-square test to examine the basic sample characteristics and their influence on the results. The Kolmogorov-Smirnov test was used for data distribution, the Kruskal-Wallis test was chosen to test the dependencies of the chosen factors, and the post-hoc test was used to understand, which factors had some influence and what type of the influence it was. Finally, the discussion of the results is presented with several recommendations.

\section{LITERATURE REVIEW}

Research into regional brands is relatively new in academic circles (Chalupová and Prokop, 2016; Kašková and Chromý, 2014). Regional brands originated in the Czech Republic in 2005, with only a few brands that later formed the Association of Regional
Brands (ARB, 2019). Because regional brands are a speciality of Central Europe, they only became interesting to researchers after their wider spread following 2010 (Stoklasa and Pitrunová, 2018). According to Jadudová et al. (2018), each V4 country has its system of regional brands with the Czech Republic as a model example. Poland has a good system of regional brands as well because all regions in Poland have Local Action Groups promoting local products. In Slovakia, first regional brands started in 2008.

No uniform regional brand definition exists at the moment (Margarisová and Vokáčová, 2016; Stoklasa and Pitrunová, 2018), the official text by the largest Czech regional brand association ARB (2019) claims: "the main objective of regional branding is to highlight individual regions (both traditional, known for example by their preserved nature, healthy environment, folk traditions, or "new" or forgotten), and to highlight the interesting products that arise here. In each of the regions, a regional brand for products has emerged which guarantees, in addition to their quality and friendliness to nature, above all their origin and connection to a certain extraordinary territory." These products are then defined in the following way (ARB, 2019): "Each region in the Czech Republic has its own unique character, given by the natural richness, culture and centuries-old traditions of its inhabitants. Also, the products originating from a certain area carry a part of this nature - the work of local craftsmen and farmers, and part of their souls, is included. Visitors are offered specific hospitality and unforgettable experiences." Čadilová (2011), former head of ARB, adds that "branded products, their promotion and sale, and perhaps a possibility to meet the producers in person and visit workshops or farms strengthen the region's attractiveness for tourists, form its character and have a positive impact on perceiving the region as a whole."

The regional brands must not be confused with a brand of a region. As Wroblewski (2016) states, local authorities are increasingly more aware that each town, commune or a whole region has an image, that can bring many benefits. This image is often transformed into a brand of the whole region. This article does not deal with this area but rather with regional brands.

This system of separate regional brands is coordinated on the national level by ARB, which acts as an umbrella organisation, giving the brands specific image, logo, rules, communication and other advantages. Each brand has its regional coordinator 
responsible for the management of the brand. The brand is awarded by an independent certification committee (in each region separately) once the uniform rules have been met. A brand is intended for region's visitors, who can explore the region and enjoy the atmosphere in a new, unusual way, as well as residents who can support their local manufacturers by purchasing branded products. Thanks to the brand, manufacturers notably benefit from a joint promotion of their products, new contacts and new forms of cooperation (ARB, 2019).

Regional brands are becoming well known in the Czech Republic (Chalupová and Prokop, 2016). Yet, consumers are becoming confused by all the various brands and what these brands should guarantee (Vokáčová et al., 2017; Chalupová and Prokop, 2016; Stoklasa and Pitrunová, 2018; Stoklasa, 2015). That is why the focus of this article is not on just one out of hundreds of brands but rather on their group with many similar factors. These similar factors are also observed in relation to their customers, such as the demographic factors used for segmentation. For example, Gajanova et al. (2019) concluded that there is a statistical dependence between age and brand loyalty, but no statistical dependence between gender and brand loyalty.

The Technology Acceptance Model (TAM) is a suitable tool to help understand how technology is changing, as well as the purchasing behaviour of consumers. The original TAM has been created by
Davis, Bagozzi and Warshaw (1989) to predict the acceptability of an information system. Later, the model has been upgraded to TAM2 by Venkatesh and Davis (2000), and then, TAM3 was designed for e-commerce. However, the model became popular and widely modified for different purposes. Not all of the models can be used for all areas of research. As proven by Ejdys et al. (2019), consumers perceive risk and security differently in technologies offered by the private sector and public institutions. Tripopsukal (2018) proposed a combination of the TAM model and the TOE framework creating an integrated TAMTOE model. Bauerová and Klepek (2017) proposed a modified version of the theoretical e-grocery shopping acceptance model, which is very suitable for Regional Branding (Fig. 1). The research did not use the whole modified TAM model but rather the ideas behind its way of functioning (e.g. ease of use, usefulness, shopping attitude and intention). For example, Ejdys (2018) indicated that the ease of use could have a statistically significant influence on technology trust. This has a positive impact on the trust in this technology (Mou et al., 2017) and leads to the way these changes manifest on the outside (a circle of new technology changing the consumer behaviour changing the company behaviour etc.) - digital marketing.

Tiago and Verissimo (2014) argued that the rapid growth of the Web has significantly modified the nature of human activities, habits and interactions. Based on their research data, the trend is accelerating

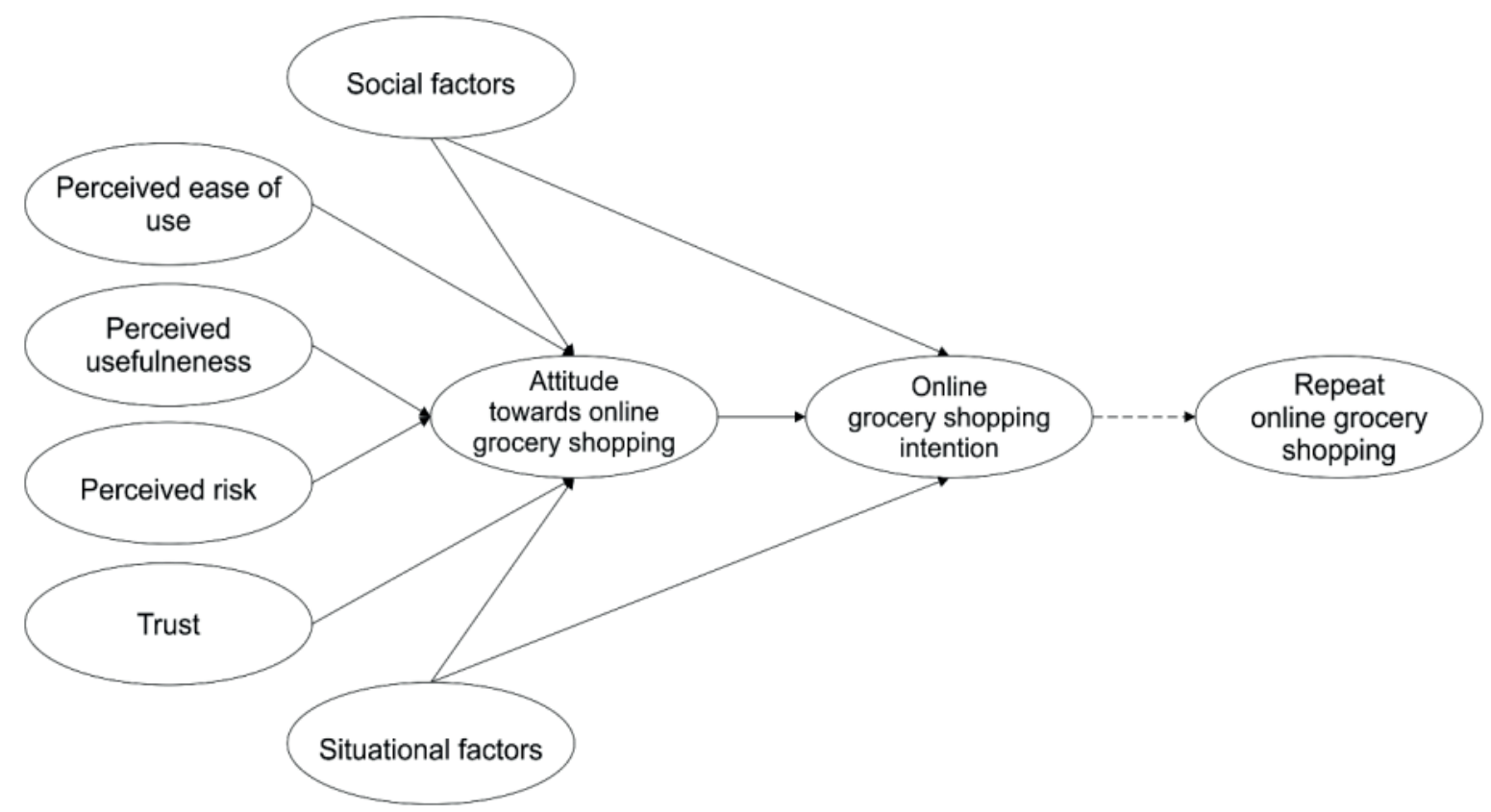

Fig. 1. Theoretical e-grocery shopping acceptance model Source: (Bauerová \& Klepek, 2017). 
itself as the rapid growth forces companies to adapt or die. Rust (2019) identified the key technological trends as companies being able to transport more information with their customers and customers utilising more information. This all leads to customers requiring online presence of companies.

Kannan and Li (2017) proposed a framework for research in digital marketing, stating that digital technology influences the environment (consumer behaviour), company (marketing mix) and outcomes. Digital technologies are providing customers with information, change the funnel, expectations, how companies need to communicate etc. If it is combined with the TAM model and applied to the area of regional brands, it is necessary to focus on customer expectations (e.g., about availability or communication) and the main tools to be used to fulfil them (e.g., web or social networks).

The following working hypotheses were formulated:

- Hypothesis 1: Sample identifiers (age, gender, education, and region) impact research results.

- Hypothesis 2: The availability preference of regional products is affected by consumer identifying factors.

- Hypothesis 3: The website perception of regional products is affected by consumer identifying factors.

- Hypothesis 4: The social media perception of regional products is affected by consumer identifying factors.

\section{RESEARCH METHODS}

The starting point was a literature review (Stoklasa and Pitrunová, 2018) that uncovered the gaps in areas that needed focus, mainly, consumer perceptions of high-quality products, important characteristics of regional products, characteristics of buyers, general purchasing behaviour when buying these products, and changes due to technology. Regional brands as they are understood in Central Europe are under-researched. It is apparent that technology is changing the way consumers purchase products, so it has to change the way they perceive the purchasing process for regional products as well. This led to a follow-up article investigating the online presence of regional brands (Pitrunová and Stoklasa, 2018). Conclusions were made regarding the message communicated by regional brands about their regional products, channels used, and the type of content, on which they focus. After these two articles, a questionnaire was designed, and the survey was carried out by a professional marketing research agency Ipsos in January 2019. The questionnaire was structured into three parts. This article uses the third part, which focused on the technology behind the TAM model. It was a battery of 19 statements that started with a general question "How important is this statement when purchasing regional products?" It used the Likert scale from "strongly agree" to "strongly disagree". The questionnaire was introduced with a thorough description of regional brands and regional products (with logos, pictures and plenty of text), to make sure the respondents were certain about the topic and terminology.

In econometric statistical testing, the following logic is used: the data needs to be tested, followed by testing the dependencies of variables, and further testing of groups that influence the results. At first, the one-way Chi-Square test of good compliance is used to test basic sample characteristics, i.e. find out, which of these are affecting the research results. Followed with one sample Kolmogorov-Smirnov (further as K-S) test to test the data distribution and whether the tested variable follows a normal distribution. Then, the dependencies can be tested with the two-way Chi-Square, ANOVA or Kruskal-Wallis test, depending on the data distribution from the K-S test. Finally, a post-hoc test suitable for the type of analysis can be chosen to better understand the group of factors that influence the results and how (Saunders, Lewis and Thornhill, 2009; Murakami and Lee, 2015).

The sample consisted of 1050 respondents of the Czech Republic. The data were obtained through questionnaire research conducted by professional marketing research agency Ipsos. As identifiers, it used age, gender, education, region, the size of the place of residence and the frequency of online purchases; however, the last two were not used in this article due to their irrelevance for the topic and space restrictions. The Czech Republic has 14 regions. This identifier was included because the regional brands were of different strength in different regions. The sample characteristics can be seen in Tab. 1 and 2.

The first test used the one-way Chi-Square test of good compliance to check the basic characteristics of age, gender, region and education. The test was performed at a significance level $\alpha=0.05$, i.e. $5 \%$. Due to space limitations, these four separate hypotheses about the four identifiers were worded into one line.

- H0: Age / gender / region / education do not affect research results. 
Tab. 1. Sample profile - gender, age, education

\begin{tabular}{|l|l|r|r|}
\hline CRITERION & \multicolumn{1}{|c|}{ Group } & \multicolumn{1}{c|}{$\begin{array}{c}\text { ABSOLUTE } \\
\text { FREQUENCY }\end{array}$} & $\begin{array}{c}\text { RELATIVE } \\
\text { FREQUENCY [\%] }\end{array}$ \\
\hline Gender & Male & 536 & 51.05 \\
\hline & Female & 514 & 48.95 \\
\hline Age & $18-25$ & 166 & 15.81 \\
\hline & $26-35$ & 202 & 19.24 \\
\hline & $36-45$ & 216 & 20.57 \\
\hline & $46-55$ & 179 & 17.05 \\
\hline & $56-65$ & 287 & 27.33 \\
\hline Education & Primary & 115 & 10.95 \\
\hline & Skilled & 375 & 35.71 \\
\hline & Secondary & 398 & 37.90 \\
\hline & University & 162 & 15.43 \\
\hline
\end{tabular}

Tab. 2. Sample profile - region

\begin{tabular}{|l|r|}
\hline \multicolumn{1}{|c|}{ REGION } & \multicolumn{1}{|c|}{ ABS. FREQUENCY } \\
\hline Praha & 149 \\
\hline Středočeský & 129 \\
\hline Moravskoslezský & 124 \\
\hline Jihomoravský & 109 \\
\hline Ústecký & 93 \\
\hline Zlínský & 63 \\
\hline Jihočeský & 60 \\
\hline Olomoucký & 59 \\
\hline Pardubický & 54 \\
\hline Královehradecký & 52 \\
\hline Plzeňský & 48 \\
\hline Vysočina & 48 \\
\hline Liberecký & 37 \\
\hline Karlovarský & 25 \\
\hline
\end{tabular}

- H1: Age / gender / region / education affect research results.

The test criteria were $30.990,0.461,256.933$ and 239.516. The value of Sig. 0.000 was less than the set value of significance level. Thus, the null hypothesis (H0) on the independence of individual characters was rejected while the alternative (H1) hypothesis regarding the influence of age, region and education on the research results was accepted. The gender identifier had the Sig. 0.497 and the null hypothesis was accepted. It was, therefore, concluded that age, region and education had an impact on the research results.

\section{RESEARCH RESULTS}

This article focused on the second battery of statements dealing with the influence of technology on the purchase of regional brands. The battery had a general question: How important is this statement when purchasing regional products? The battery consisted of 19 statements where respondents had to specify their level of agreement on the five-level Likert scale (Tab. 3). For interpretation, the logic of primary school grading was used where 1 (strongly agree) was the best and 5 (strongly disagree) was the worst score. The battery could be broken down into three blocks, where the first focused on availability, the second - on the web, and the third - on social networks.

The first block (statements 1 and 2) dealt with the availability of regional products, as it was one of the research topics in other parts of this research study (other articles), and was a fundamental part of the TAM model. The online availability, e.g. in an e-shop, was preferred by the respondents with $36.6 \%$ of positive answers, only $22.1 \%$ - negative answers, and an average of 2.8. Mobile applications were not as preferred with only $19.8 \%$ of positive answers, $36.6 \%$ negative answers, and an average of 3.2.

The second block (statements 3-11 and 18) dealt with websites. Generally, there were more than 50\% of positive answers and low averages (2.3-2.5) for all statements (well designed, good product labels with pictures, easy navigation and search, product delivery options, payment options, reviews) except for mobile optimisation $(42 \%, 2.7)$, event promotions $(41 \%, 2.7)$ and reports from events $(31.9 \%, 2.9)$. Customers have put high stress on the quality of websites.

The third block (statements 13-17, 19 and 12) dealt with social networks and were bundled with newsletters. Respondents reacted similarly to the first three statements about Facebook, the need to post regularly about events, brands and producers, other topics, all with around $30 \%$ of positive answers and an average of 2.9. It is worth noting that all of them had around 25\% of negative answers. Regular communication on Instagram and YouTube had both around $15 \%$ of positive answers, $25 \%$ - negative answers, and an average of 3.3. Sharing opinions and experience with other buyers was reflected positively with $54.6 \%$ of positive answers and an average of 2.4 . Newsletters, the issues were also perceived rather positively with $40.7 \%$ of positive answers and an average of 2.7. 
Tab. 3. Research results for all 19 statements

\begin{tabular}{|c|c|c|c|c|c|c|}
\hline No. & Statement & $\begin{array}{l}\text { STRONGLY } \\
\text { AGREE }\end{array}$ & AgReE & Neutral & DISAGREE & $\begin{array}{l}\text { STRONGLY } \\
\text { DISAGREE }\end{array}$ \\
\hline 1 & To be available online, e.g. in an e-shop & 6.9 & 29.7 & 41.3 & 17.0 & 5.1 \\
\hline 2 & To be available through a mobile app. & 3.7 & 16.1 & 43.5 & 25.3 & 11.3 \\
\hline 3 & For the producer to have a well-designed web & 10.9 & 42.1 & 33.6 & 9.8 & 3.6 \\
\hline 4 & Web has good product labels including photos & 16.2 & 47.0 & 27.0 & 6.9 & 2.9 \\
\hline 5 & Easy web navigation and search for desired information & 15.5 & 47.8 & 28.4 & 5.3 & 3.0 \\
\hline 6 & More product delivery options & 11.1 & 46.0 & 33.4 & 7.3 & 2.1 \\
\hline 7 & Web is optimised for mobile phones & 9.0 & 33.0 & 39.4 & 13.1 & 5.5 \\
\hline 8 & More payment options & 12.3 & 49.3 & 30.2 & 5.5 & 2.7 \\
\hline 9 & Web contains event promotions & 7.3 & 33.7 & 42.7 & 12.0 & 4.3 \\
\hline 10 & Web contains reports from events and more & 5.4 & 26.5 & 46.7 & 16.6 & 4.9 \\
\hline 11 & $\begin{array}{l}\text { Web contains articles about products, producers, produc- } \\
\text { tion, etc. }\end{array}$ & 10.6 & 42.3 & 36.8 & 7.3 & 3.0 \\
\hline 12 & Possibility to send newsletters about special offers & 7.7 & 33.0 & 40.7 & 12.9 & 5.7 \\
\hline 13 & $\begin{array}{l}\text { Make regular events on Facebook about traditions, regions } \\
\text { and producers }\end{array}$ & 7.2 & 23.3 & 44.4 & 16.7 & 8.4 \\
\hline 14 & $\begin{array}{l}\text { Make regular updates on brand and producer news on } \\
\text { Facebook }\end{array}$ & 6.0 & 23.9 & 46.8 & 15.4 & 7.9 \\
\hline 15 & $\begin{array}{l}\text { Make articles/videos on Facebook to inform about other } \\
\text { topics in the region without promoting the producers }\end{array}$ & 6.0 & 23.0 & 46.6 & 15.8 & 8.6 \\
\hline 16 & Regular communication on Instagram & 3.4 & 12.4 & 48.7 & 23.6 & 11.9 \\
\hline 17 & Regular communication on YouTube & 3.7 & 11.8 & 49.5 & 23.9 & 11.0 \\
\hline 18 & Web contains reviews & 18.4 & 43.2 & 28.6 & 6.6 & 3.2 \\
\hline 19 & I can share my opinions and experience with other buyers & 13.9 & 40.7 & 33.5 & 7.7 & 4.2 \\
\hline
\end{tabular}

Aiming to test the data for dependencies, the data distribution had to be tested first. The one-sample Kolmogorov-Smirnov test was used to test if a variable followed a normal distribution. The table with all the data was not included due to space limitations. All the Asymp. Sig. (2-tailed) were 0.000 , which means that the null hypothesis about the normal distribution of the data was rejected and the alternative hypothesis about data not having normal distribution was accepted. The end result being that ANOVA can't be used but the process had to continue with the Kruskal-Wallis test. The result was supported by all the $\mathrm{K}-\mathrm{S}$ values in normal parameters, most extreme differences and test statistics.

The non-parametric Kruskal-Wallis test was used to test the working hypothesis on the overall availability preference of regional products and chosen sample identifiers. The working hypothesis was converted to statistical in the following wording:

- H0: The availability preference of regional products doesn't differ based on consumer identifying factors.
- H1: The availability preference of regional products differs based on consumer identifying factors.

Statements no. 1 and 2 and identifying factors (age, gender, region and education) were tested. The test was performed at a significance level $\alpha=0.05$, i.e. $5 \%$.

The Kruskal-Wallis test results (Tab. 4) manifest that the null hypothesis cannot be rejected, and it has to be stated that the availability preference of regional

Tab. 4. Kruskal-Wallis results for the first block of statements no. 1 and 2

\begin{tabular}{|l|l|r|r|}
\hline \multirow{2}{*}{ IDENTIFIER } & \multicolumn{1}{|c|}{ Results } & \multicolumn{1}{c|}{ S. 1 } & \multicolumn{1}{c|}{ S. 2} \\
\hline \multirow{3}{*}{ Age } & Kruskal-Wallis H & 7.195 & 5.855 \\
\cline { 2 - 4 } & Asymp. Sig. & 0.126 & 0.210 \\
\hline \multirow{3}{*}{ Gender } & Kruskal-Wallis H & 0.036 & 0.000 \\
\cline { 2 - 4 } & Asymp. Sig. & 0.850 & 0.997 \\
\hline \multirow{3}{*}{ Education } & Kruskal-Wallis H & 2.030 & 7.709 \\
\cline { 2 - 4 } & Asymp. Sig. & 0.566 & 0.052 \\
\hline \multirow{3}{*}{ Region } & Kruskal-Wallis H & 17.901 & 10.665 \\
\cline { 2 - 4 } & Asymp. Sig. & 0.161 & 0.639 \\
\hline
\end{tabular}


products does not differ based on consumer identifying factors. However, education warrants further investigation.

The non-parametric Kruskal-Wallis test was used to test the working hypothesis on the overall website perception of regional products and chosen sample identifiers. The working hypothesis was converted to statistical in the following wording:

- H0: The website perception of regional products does not differ based on consumer identifying factors.

- H1: The website perception of regional products differs based on consumer identifying factors

Statements no. 3-11 and 18 and identifying factors (age, gender, region and education) were tested. The test was performed at a significance level $a=0.05$, i.e. $5 \%$.

Results of the Kruskal-Wallis test shown in Tab. 5 manifest that the null hypothesis cannot be rejected, and it has to be stated that the availability preference of regional products does not differ based on consumer identifying factors. However, 5 of the age results, 6 of the gender results, 3 of the education results and 1 of the region results warrant further investigation.

The non-parametric Kruskal-Wallis test was used to test the working hypothesis on the overall social media perception of regional products and chosen sample identifiers. The working hypothesis was converted to statistical in the following wording:

- H0: The social media perception of regional products does not differ based on consumer identifying factors.

- H1: The social media perception of regional products differs based on consumer identifying factors. Statements no. 13-17, 19 and 12 and identifying factors (age, gender, region and education) were tested. The test was performed at a significance level $\alpha$ $=0.05$, i.e. $5 \%$.

Results of the Kruskal-Wallis test (Tab. 6) manifest that the null hypothesis cannot be rejected, and it has to be stated that the availability preference of regional products does not differ based on consumer identifying factors. However, 3 of the age results, 5 of the gender results and 4 of the education results warrant further investigation.

Tab. 5. Kruskal-Wallis results for the second block of statements no. 3-11 and 18

\begin{tabular}{|c|c|c|c|c|c|c|c|c|c|c|c|}
\hline IDENTIFIER & RESULtS & S. 3 & S. 4 & S. 5 & S. 6 & S. 7 & S. 8 & S. 9 & S. 10 & S. 11 & S. 18 \\
\hline \multirow[t]{2}{*}{ Age } & Kruskal-Wallis H & 3.794 & 9.120 & 6.571 & 6.157 & 4.183 & 11.530 & 18.092 & 13.455 & 9.350 & 4.739 \\
\hline & Asymp. Sig. & 0.435 & 0.058 & 0.160 & 0.188 & 0.382 & 0.021 & 0.001 & 0.009 & 0.053 & 0.315 \\
\hline \multirow[t]{2}{*}{ Gender } & Kruskal-Wallis $\mathrm{H}$ & 3.200 & 1.750 & 4.493 & 0.599 & 0.107 & 2.703 & 2.711 & 0.108 & 2.742 & 5.661 \\
\hline & Asymp. Sig. & 0.074 & 0.186 & 0.034 & 0.439 & 0.744 & 0.099 & 0.099 & 0.742 & 0.098 & 0.017 \\
\hline \multirow[t]{2}{*}{ Education } & Kruskal-Wallis H & 6.042 & 10.807 & 4.271 & 2.604 & 0.814 & 7.123 & 5.300 & 6.261 & 5.074 & 2.400 \\
\hline & Asymp. Sig. & 0.110 & 0.013 & 0.234 & 0.457 & 0.846 & 0.068 & 0.151 & 0.100 & 0.166 & 0.494 \\
\hline \multirow[t]{2}{*}{ Region } & Kruskal-Wallis H & 12.440 & 16.056 & 16.246 & 9.974 & 14.858 & 7.111 & 25.969 & 14.731 & 9.229 & 12.442 \\
\hline & Asymp. Sig. & 0.492 & 0.246 & 0.236 & 0.696 & 0.316 & 0.896 & 0.017 & 0.324 & 0.755 & 0.492 \\
\hline
\end{tabular}

Tab. 6. Kruskal-Wallis results for the second block of statements no. 13-17, 19 and 12

\begin{tabular}{|c|c|c|c|c|c|c|c|c|}
\hline IDENTIFIER & RESULtS & S. 13 & S. 14 & S. 15 & S. 16 & S. 17 & S. 19 & S. 12 \\
\hline \multirow[t]{2}{*}{ Age } & $\begin{array}{l}\text { Kruskal- } \\
\text { Wallis H }\end{array}$ & 0.797 & 2.523 & 1.399 & 7.843 & 1.283 & 9.659 & 26.671 \\
\hline & Asymp. Sig. & 0.939 & 0.641 & 0.844 & 0.097 & 0.864 & 0.047 & 0.000 \\
\hline \multirow[t]{2}{*}{ Gender } & $\begin{array}{l}\text { Kruskal- } \\
\text { Wallis H }\end{array}$ & 10.385 & 12.262 & 8.446 & 0.091 & 0.758 & 6.426 & 6.670 \\
\hline & Asymp. Sig. & 0.001 & 0.000 & 0.004 & 0.763 & 0.384 & 0.011 & 0.010 \\
\hline \multirow[t]{2}{*}{ Education } & $\begin{array}{l}\text { Kruskal- } \\
\text { Wallis H }\end{array}$ & 2.357 & 9.486 & 6.453 & 14.633 & 14.508 & 1.007 & 5.852 \\
\hline & Asymp. Sig. & 0.502 & 0.023 & 0.092 & 0.002 & 0.002 & 0.800 & $0.11 \mathrm{c}$ \\
\hline \multirow[t]{2}{*}{ Region } & $\begin{array}{l}\text { Kruskal- } \\
\text { Wallis H }\end{array}$ & 14.123 & 13.032 & 14.604 & 6.250 & 7.663 & 10.008 & 8.259 \\
\hline & Asymp. Sig. & 0.365 & 0.445 & 0.333 & 0.937 & 0.865 & 0.693 & 0.826 \\
\hline
\end{tabular}


Hypothesis 1 was accepted, hypotheses 2, 3 and 4 were rejected. Although all the null hypotheses about independency of variables have been accepted, this research process has been specifically chosen for its power to find the groups that influenced the results in post-hoc testing. Out of the 19 tested statements, if common significance level $\alpha=0.1$, i.e. $10 \%$ was considered, 28 showed the dependency of variables, which is $37 \%$. Gender with 11 , and both age and education had 8 cases, where they influenced the result, mainly in the website and social networks perception.

\section{DISCUSSION OF THE RESULTS}

Based on the previous research (described in chapter 3), the following premises were related to the research topics: online availability will be highly preferred; websites will be important, consumers will prefer user experience (UX) to expertise and up-todate information, and social media will not play any significant role because of age/gender/education structure of the most engaged consumers.

Online availability in e-shops was slightly preferred and mobile - slightly unpreferred, which was surprising. All the studies and other research papers (Bauerová and Klepek, 2018; Statista, 2019) pointed to consumers preferring online and mobile availability. However, Czechs, although being record online shoppers (Statcounter, 2019), do not prefer shopping online for food products (Špačková, 2018). According to Nielsen research (Špačková, 2018), the barriers were the inability to view the product, additional costs, concerns about product quality. However, online grocery shopping services, such as Košík, Rohlík, Plnátaška, Tesco Online, are growing more popular in the Czech Republic. Currently, only two of the regional brands, very small ones, have an e-shop (Pitrunová and Stoklasa, 2018). Using TAM terminology, it could be stated that the attitude is there, intention as well, but repeat purchase is limited due to one of the factors (perceived risk vs ease of use and usefulness).

Website qualities were more in-line with the premise. Consumers prefer good UX, but also require high expertise, and do not need to have an overabundance of content that would be better suited to social media. The most important for consumers was easy use, navigation and search. Respondents placed the same emphasis on product and photo labels. In addition, various payment options were highly preferred.
Nielsen research (Špačková, 2018) supports the findings, as the high stress is put on a high-quality website, which needs to be convenient and easy to navigate. Surprising seemed the answers about web content, with the high preference of quality articles about events, products, promotions and more. But respondents ranked those features way below other web factors. The author could not find any explanation other than that such content belonging to social networks.

The first recommendation is based on the culmination of several trends that were observed in the past decade (Stoklasa, 2015) and the results and discussion presented in this article. The online grocery shopping is perceived as only a supporting channel, not the main one (see previous comments). Having an e-shop can be beneficial, but it does not have to be given a high priority for regional brands. Online communication, however, is important. And the number one priority should be a high-quality website, with good product labels and photographs (it overcomes one of the barriers of not seeing the products, see in above). This leads to a belief that investing in the web presence is the best way to spend the limited budget available to regional brands. The characteristics of the web presence were described in the previous paragraph and can be clearly seen in the results, as well as in the previous article by Pitrunová and Stoklasa (2018). Also, they are supported by other researchers, for example, Roy, Rau and Mandal (2017) proved that information related to products is highly important, transaction detail and the quality of the system. Since the brands will need to be focusing on the product labels and photographs, it is also recommended to couple it with a hybrid e-shop as can be see functioning successfully at, for example, "Farma domů" [Farm to your home] (Farmadomů.cz, 2019). Customers can browse the products and order them online but have to pick them up during a specific day or days. This way of purchasing brings together the ease and convenience of online shopping with the possibility to see the products (touch and smell them). But that is only half of the recommendation. The situation with product protective branding in the Czech Republic is confusing to consumers, as there are hundreds of brands (Stoklasa, 2015; Weikert, 2016) that guarantee something, but consumers have no idea what. On top of all these brands is the stateowned "Regionální potravina" [Regional food], a project that has consumed hundreds of millions CZK with questionable results (Stoklasa, 2015; Horáček 2014). Moreover, regional brands are mostly small (micro), run by enthusiasts to help others, with 
no profit goals, and with a limited budget. That is why the recommendation of a high-quality website with a hybrid e-shop has to be realised using the "Regionální potravina" as a platform. It could finally unite the characteristics that brands guarantee, educate consumers nation-wide, provide an umbrella over all the micro-brands giving them a chance to have a high-quality website having a standardized layout, also cutting the costs. And the largest benefiting group is consumers. After all, the governmentrun brands have one of their goals as "the generation of market potential is one of the priority tasks of the marketing of these certification systems and must be continuously formed according to the requirements of end consumers" (Michal et al., 2018).

Respondents don't see social media as crucial. Opinions on Facebook communication were neutral, Instagram and YouTube were rather negative, the only positively accepted form of communication was newsletters. Paradoxically, respondents wanted to be able to share their opinions and experience with other buyers. There is a possibility to offer a discussion feature on the website, under the products or in a dedicated forum.

The identifiers will be used to construct recommendations about customer segments. The K-W post-hoc test using a pairwise comparison, the Dunn's test with the Bonferroni correction, can find the statistically significant differences, rank the groups and assign values. It is used to find, e.g., the gender that influences the results and how. In the first battery of statements, the influence of gender was non-existent, but regions played a huge role. In the second battery, the regions showed minimal statistical significance (only 1 of 19 statements) but in terms of gender, it was considerable (11 out of 19). Women wanted to be much more informed about everything (statements 3 , $5,8,9,11$ and 18), e.g. in terms of web navigation, product labels, more options etc., and women were more positive about the communication on Facebook (statements 13-15), wanted more opportunities to share their experience (statement 19), and were more positive towards newsletters (statement 12). As regards the age, the age group of 46-55 was the most positive (statement $4,8,9,10,16,19$ and 12), the youngest age group 18-25 was usually the most negative (all statements except for Instagram and YouTube, and $56 \%$ of them perceived easy website navigation as essential). Result supporting this can be seen in Jakubowska and Radzymińska (2019), where Czech young-adults presented much weaker health-related and environmental attitudes towards food products than, e.g., the Polish. In regard to education, the more educated people, the more they agreed with more information, more options and more adaptation (statements 4, 8, 10 and 14). Respondents with highschool education preferred Instagram and YouTube (statements 16 and 17).

The second recommendation is to pursue good content on the website, use the same content on Facebook, target women, of 46-55, with higher education. Although the preferences for content on the website were not overly positive, they were still rather positive, and the content was still incredibly important. Because of the age, gender and education structure, it was clear that it does not need to be young and flashy, but can rather be about recipes, good health, traditions, event reports etc. This content then can be recycled on Facebook. It is recommended to ignore Instagram and YouTube for now, meaning to not produce any special content for the said networks.

To summarise, technology is slowly changing the purchasing behaviour of customers buying regional products. These originally traditional, local and, thus, offline products need to have a good website, need to start exploring the possibilities to be available online and be present on social media.

\section{CONCLUSIONS}

Online availability of e-shops was slightly preferred and mobile availability was slightly unpreferred. In regard to websites, consumers prefer good UX, but also require high expertise, and do not need to have an overabundance of content that would be better suited to social media. The most important features for consumers are easy use, navigation and search. Respondents place the same emphasis on product and photo labels. In addition, various payment options were highly preferred. Respondents do not see social media as crucial. Opinions on Facebook communication were neutral, Instagram and YouTube were rather negative, and the only positively accepted form of communication was newsletters. Paradoxically, respondents wanted to be able to share their opinions and experience with other buyers. The recommendation is aimed at the state-owned "Regionální potravina" that can be used as an umbrella to provide basic online functionality services to all small regional brands. It will help all stakeholders, as the state gets support for local producers, who get their products more easily to customers, who get quality products. A hybrid e-shop variant 
was also proposed, which is suitable due to the limitations that these brands have.

The sample identifiers were also used to formulate segmentation criteria usable for the online presence of regional brands. Women wanted to be much more informed about everything, e.g. in terms of web navigation, product labels, more options etc., and women were, in general, more positive about the communication on Facebook, wanted to share their experience more, and were more positive towards newsletters. In regard to age, the age group of 46-55 was the most positive, and the youngest age group of 18-25 was usually the most negative. In regard to education, the more educated were the respondents, the more they agreed with more information, more options, and more adaptation. Thus, it is recommended that brands focus on highly educated women of 46-55.

Technology is slowly changing the purchasing behaviour of customers buying regional products. These originally traditional, local and, thus, offline products need to have a good website, need to start exploring the possibilities to be available online and have a limited presence on social media.

The results of this study can be used to improve the functioning of regional brands in the Czech Republic and can serve as guidelines for other countries with similar systems. Technology is changing consumer behaviour and even products that are traditional have to adapt fast. The limitations of this study are mainly related to the lack of previous research studies on the topic and techniques used to evaluate the data. As described in the literature review, the regional brands are only relevant in a small number of countries and there is no validated methodology that could be used. Each of the chosen data analysis techniques has its advantages and disadvantages and there might be better ones to use that were not attempted. Future research should focus on developing a model for technology acceptance in the area of regional brands, including testing various data analysis techniques. Future research might also be focused on the role of online presence in building regional brands.

\section{ACKNOWLEDGEMENT}

This research was financially supported by the student grant competition project SGS/7/2017: "Acceptance of technology from the perspective of marketing tools."

\section{LITERATURE}

Bauerova, R., \& Klepek, M. (2017). The Theoretical Framework for the Application of the TAM in Online Grocery Shopping. Working Paper in Interdisciplinary Economics and Business Research no. 44. Karviná, Czech Republic: Silesian University in Opava, School of Business Administration in Karviná.

Bauerová, R., \& Klepek, M. (2018). Technology Acceptance as a Determinant of Online Grocery Shopping Adoption. Acta Universitatis Agriculturae et Silviculturae Mendelianae Brunensis, 66(3), 737-746.

Čadilová K. (2011). Regional Branding throughout Europe. Litomyšl, Czech Republic: Asociace regionálních značek.

Chalupova, M., \& Prokop, M. (2016). Awareness of the Vysočina regional food labels with context of their media presence. Acta Universitatis Agriculturae et Silviculturae Mendelianae Brunensis, 64(1), 223-234.

Davis, F., Bagozzi, R., \& Warshaw, R. (1989). User Acceptance of Computer Technology: A Comparison of Two Theoretical Models. Management Science, 35, 982-1003.

Ejdys, J. (2018). Building technology trust in ICT application at a university. International Journal of Emerging Markets, 13(5), 980-997.

Ejdys, J., Ginevicius, R., Rozsa, Z., \& Janoskova, K. (2019). The role of perceived risk and security level in building trust in E-government solutions. E+M Economics and Management, 22(3), 220-235.

Farmadomů. (2019). O nás [About us]. Retrieved from http://www.farmadomu.cz/o-nas/

Gajanova, L., Nadanyiova, M., \& Moravcikova, D. (2019). The use of demographic segmentation to creating marketing strategy of brand loyalty. Sticentific Annals of Economics and Business, 66(1), 65-84.

Horáček, F. (2014). Chaos za stovky milionů. Značek kvality je na českém trhu príliš, iDnes [Chaos worth hundreds of millions. Too many quality brands on the Czech market]. Retrieved from https://www.idnes. cz/ekonomika/domaci/chaos-v-ceskych-znackachkvality.A140120_133534_ekonomika_fih

Jadud’ová, J., Marková, I., Vicianová, J., Bohers, A., \& Murin, I. (2018). Study of Consumer Preferences of Regional Labeling. Slovak Case Study. European Countryside, 10(3), 429-441.

Jakubowska, D., \& Radzymińska, M. (2019). Health and environmental attitudes and values in food choices: a comparative study for Poland and Czech Republic. Oeconomia Copernicana, 10(3), 433-452.

Kannan, P. K., \& Li, H. A. (2017). Digital marketing: A framework, review and research agenda. International Journal of Research in Marketing, 34(1), 22-45.

Kašková, M., \& Chromý, P. (2014). Regional product labelling as part of the region formation process. The case of Czechia. AUC Geographica, 49(2), 87-98.

Michal, J., Sujová, A., \& Březina, D. (2018). The importance of products made of certified wood materials to consumers in the Czech Republic. Forum Scientiae Oeconomia, 6(3), 119-131. 
Mou, J., Shin, D.-H., \& Cohen, J. (2017), Understanding trust and perceived usefulness in the consumer acceptance of an e-service: a longitudinal investigation. Behaviour \& Information Technology, 36(2), 125-139.

Murakami, H., \& Lee, S. K. (2015). Unbiasedness and biasedness of the Jonckheere-Terpstra and the Kruskal-Wallis tests. Journal of the Korean Statistical Society, 44(3), 342-351.

Pitrunová E., \& Stoklasa, M. (2018). Online presence of brands in product protective branding. In Marketing Identity (pp. 236-247). Trnava, Slovakia: University of Ss. Cyril and Methodius University.

Roy, S., Raju, A., \& Mandal, S. (2017). An empirical investigation on e-retailer agility, customer satisfaction, commitment and loyalty. Business: Theory and Practice, 18, 97-108.

Rust, R. T. (2019). The future of marketing. International Journal of Research in Marketing, 36(3), 2-12.

Saunders, M., Lewis, P., \& Thornhill, A. (2009). Research methods for business students. Harlow, Great Britain: Pearson Education.

Špačková, I. (2018). Czechs and Shopping: They report love for national goods but spend mainly on discounts. Retrieved from https://zpravy.aktualne.cz/finance/nakupovani/cesi-a-nakupovani-hlasaji-lasku-k-narodnimu-zbozi-utraceji-v/r fc7f5926d78d11e890ecac $1 \mathrm{f} 6 \mathrm{~b} 220 \mathrm{ee} 8 /$ ?utm_source $=$ www.seznam.cz\&utm medium $=$ z-boxiku\&redirected $=1549485613$

Statcounter. (2019). Desktop vs Mobile vs Tablet Market Share Worldwide. Retrieved from http:// gs.statcounter.com/platform-market-share/desktopmobile-tablet?fbclid=IwAR1OUV-56mHYYtNQ_jBZi3kMUC3dCwRk6ed7vcaU-I9yGA821ZeZqZennk

Statista. (2019). Online grocery shopping. Retrieved from http://gs.statcounter.com/platform-market-share/ desktop-mobile-tablet?fbclid=IwAR1OUV56mHYYtNQ_j-BZi3kMUC3dCwRk6ed7vcaUI9yGA821ZeZqZennk

Stoklasa, M. (2015). Possibilities of using regional marking of product in Moravian-Silesian region through crosscultural marketing. Karviná, Czech Republic: Silesian University in Opava, Faculty of Business Administration in Karviná.

Stoklasa, M., \& Pitrunová, E. (2018). Past and future research trends of Regional Brands with accent to technology. Working Paper in Interdisciplinary Economics and Business Research no. 51. Karviná, Czech Republic: Silesian University in Opava, School of Business Administration in Karviná.

Tiago, M. T. P. M. B., \& Verissimo, J. M. C. (2014). Digital marketing and social media: Why bother? Business Horizons, 57(6), 703-708.

Tripopsakul, S. (2018). Social media adoption as a business platform: an integrated TAM-TOE framework. Polish Journal of Management Studies, 18(2), 350-362.

Venkatesh, V., \& Davis, F. D. (2000). A theoretical extension of the technology acceptance model: Four longitudinal field studies. Management Science, 46(2), 186-204.

Vokáčová, L., Margarisová, K., Huml, J., \& Čerkasov, J. (2017). Regional bands as an attribute of product quality. Acta Universitatis Agriculturae et Silviculturae Mendelianae Brunensis, 65(6), 2131-2140.

Weikert, P. (2016). Ve značkovém pralese [In the branded jungle]. Retrieved from https://www.euro.cz/byznys/ ve-znackovem-pralese- 1287183

Wroblevski, L. (2016). Creating an image of a region - Euroregion Beskydy and Euroregion Cieszyn Silesia examples. Engineering Management in Production and Services, 8(1), 91-100. 